\title{
LANGUAGE ETHICS IN DAILY LIFE
}

\author{
Muhammad Daffa Soelistijono Putra ${ }^{1,}$ Naila Silvana ${ }^{2,}$ Alda Krisna Wardani ${ }^{3}$, \\ Qoni' Atuzzahra Soegijarso ${ }^{4}$, Moses Glorino Rumambo Pandin ${ }^{5}$
}

\begin{abstract}
Department of English Language and Literature, Faculty of Humanities, Universitas Airlangga muhammad.daffa.soelistijono.putra-2020@fib.unair.ac.id; naila.silvana-2020@unair.ac.id; alda.krisna.wardani-2020@ fib.unair.ac.id; qoni.atuzzahra.soegijarso-2020@ fib.unair.ac.id; moses.glorino@fib.unair.ac.id
\end{abstract}

\begin{abstract}
Behavior, ethics, and also language are social things. Communication procedures or ethics can be influenced by the cultural norms of particular community groups. In the current era of life, many people still lack knowledge about ethics in language. The focus of the study of this research leads to ethical aspects of language in everyday life and is attached to the subject of this research. This research is descriptive quantitative. The research object was selected based on the knowledge of several people about language ethics. This study aims to find out how essential language ethics is in everyday life.
\end{abstract}

Keywords: Language ethics, language, communication, philosophy, morals.

\begin{abstract}
Abstrak: Tindak laku, etika dan juga berbahasa merupakan hal yang bersifat sosial. Tata cara berkomunikasi ataupun etika dapat dipengaruhi oleh norma budaya kelompok masyarakat tertentu. Di era kehidupan saat ini, banyak orang yang masih kekurangan ilmu mengenai etika dalam berbahasa. Fokus kajian dari penelitian ini bermuara pada aspek etika berbahasa dalam kehidupan sehari-hari dan terlampir di subjek penelitian akan hal ini. Penelitian ini merupakan kuantitatif deskriptif. Objek penelitian yang dipilih berdasarkan pengetahuan beberapa orang tentang etika berbahasa. Adapun hasil dari penelitian ini ialah untuk mengetahui sebagaimana pentingnya etika berbahasa dalam kehidupan sehari-hari.
\end{abstract}

Kata kunci: Etika berbahasa, bahasa, komunikasi, filsafat, moral. 


\section{CHAPTER I INTRODUCTION}

\subsection{BACKGROUND}

Language skills have an essential role in social life because it is a tool for communicating with others. Language can be said as a collection of norms and symbols in a particular group. There may also be culture and characteristics that flow in it. The similarity of language in a group usually still has differences in pronunciation, vocabulary, terms of speech, and speech. People use language as a group identity, so naturally, there is a style of language and ethics in its use. However, it should be noted that not all languages are considered to be spoken by users well. Language can be communicated well if the speakers use language ethics. Language ethics are viewed differently through norms, gender, and region.

The term "ethics" is etymologically derived from the Greek, "ethos" which means "custom"

or habit. Relation to human behavior, habits, and human character as a whole. The meaning of "ethos" also belongs to the Latin word "mores," from which the word "moral" is derived. Therefore, ethics and morals are synonyms. Ethics itself is a moral philosophy.

With the view of moral philosophy, Language Ethics in Daily Life will be discussed more deeply, especially through the perspective of norms, gender, and the area of how language adapts based on the sides mentioned. The following are some previous studies regarding the factors that influence language ethics in everyday life, but there are differences from the results of previous studies. It can be seen from the research gap as follows:

\subsection{RESEARCH GAP}




\begin{tabular}{|c|c|c|c|c|}
\hline Researchers and Year & \multicolumn{3}{|c|}{ Research Title Research } & Gaps \\
\hline Taufik Rowandy, et al (2021) & Language $\quad \mathrm{E}$ & Ethics & in & Language ethics are very \\
\hline & $\begin{array}{l}\text { Communication } \\
\text { Coaching Tool }\end{array}$ & as & $\mathrm{a}$ & $\begin{array}{l}\text { important and influential as a } \\
\text { means of coaching, and good } \\
\text { communication } \\
\text { communication that is built and } \\
\text { based on good language ethics. } \\
\text { Still, the problem only leads to } \\
\text { an institution and is not } \\
\text { explained in detail how to solve } \\
\text { the problem. }\end{array}$ \\
\hline
\end{tabular}

Achmad Wahidy (2016) Nation's Personal Mirror: Language as a communication Cleverly Speaks A Dignified Polite Behavior in Speak tool is closely related to culture. In communicating, polite behavior in speaking is a must that every language user must consider. Language politeness is reflected in the procedure for communicating through verbal signs or language procedures and is subject to cultural norms that apply when the speech or communication occurs.

M. Rus Andianto, et al (2020) Learning politeness in a language in the era Towards a Golden Indonesia

Many physical and linguistic attitudes and behaviors, which in the eyes of the elderly, are considered as neglect and violations of politeness norms. The youth themselves have realized and contributed to giving sad comments about this phenomenon.

Noibe Halawa, et al (2019)

Indonesian Language Politeness in Prohibition and Criticism of Seven Ethnicities

This study discusses using
language and making
conversations run smoothly and
comfortably. However,
everyone wants to be
understood and does not want to
be disturbed by others; in fact,
he didn't want to lose face while
communicating. Losing face
means feeling embarrassed,


humiliated,

disappointed/annoyed.

Bustomi (2019) The

The face of the Nation in the Language means expressing Mirror of Culture in ideas through sound symbols Language arbitrarily. When someone is speaking, it means he is thinking. Both oral and written, something that is poured represents what is being considered. If a person's mind is normal, the strings of sentences or expressions that are issued will undoubtedly be normal in line with his thoughts. On the other hand, if a person's thinking is disturbed or "mentally retarded", it can be assumed that the sentences and expressions that are issued will also be disturbed and unbalanced.

Based on the explanation in the table above, it can be explained that there are still gaps and updates regarding research that affect language ethics in everyday life. This indicates that the research gap needs to be studied further.

To get results related to the variables of language ethics in everyday life, the researchers made the following framework:

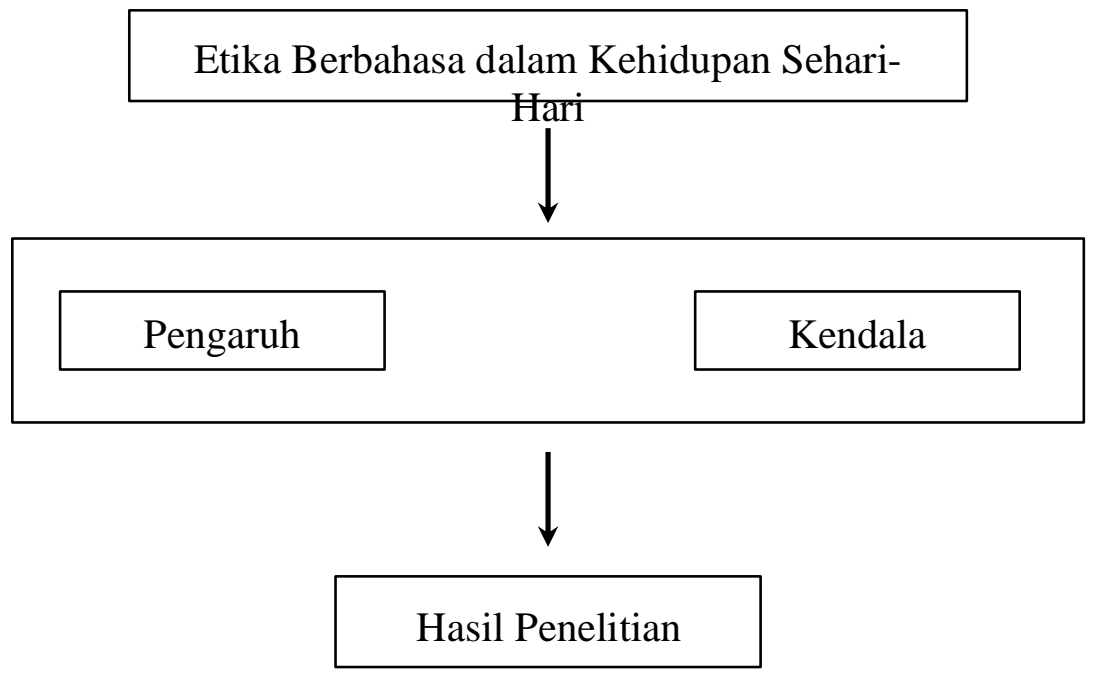


Based on the description and frame of mind in the picture above thus, in this study, the author raised the title "Language Ethics in Daily Life."

\subsection{OBJECTIVES \& BENEFITS OF THE RESEARCH}

In general, this study aims to determine how people understand the importance of language ethics in daily life. The benefits of this research can be formulated, namely being able

a. to know the extent to which people understand the importance of language ethics in daily life,

b. preserving language ethics so that when communicating, a good relationship can be established.

c. Can feel the benefits when ethics in language are intertwined.

\subsection{PROBLEM FORMULATION}

Based on this background and problems, the following are 3 problems that need to be discussed in research.

1. What do people know about language ethics in everyday life?

2. How does ethical society use language with the perspective of norms, gender, and territory?

3. Why is it important to learn about language etiquette in everyday life?

4. What benefits can be obtained from studying language ethics in everyday life? 


\section{CHAPTER II}

\section{RESEARCH METHODSRESEARCH}

\subsection{APPROACH}

In this study, we used descriptive quantitative research methods using questionnaires, in connection with the themes raised, namely Language, Literature, \& Axiology in the Digital Age in the Philosophy of Science Perspective. Descriptive quantitative method is a descriptive research method and tends to use questionnaires, interviews, in connection with the object being studied. According to Sugiyono (2017:2), quantitative research methods are research methods that have a positivism foundation, so that they can be used as a tool to examine certain samples or populations, collect data using research instruments, analyze quantitative or statistical data, which aims to have a hypothesis. which has been set.

The steps we will use are (1) data collection, (2) analyzing the data we have collected, and (3) drawing conclusions from the data we have analyzed. In terms of data collection, there are several kinds of quantitative data collection methods, which we use in this research is a literature study and share questions through thewebsite Google forms.

\subsection{DATA COLLECTION TECHNIQUES Data}

collection is one of the most important parts of a research. The technique used in this research is structured interview. Structured interview is one of the research instruments of quantitative research using the questions that have been provided along with the answer choices. According to Sugiyono (2017), structured interviewing is an interview method carried out by researchers by providing a list of written questions which then all of the answers are also available in the form of multiple choices.

\subsection{DATA ANALYSIS TECHNIQUES Data}

analysis is one of the research processes after data collection has been completed. According to Lexy J. Moleong (2000), data analysis is a process of organizing and sorting data into patterns, categories, and large description units so that themes can be found, and working hypotheses can be formulated, as suggested by the data. 
To process the data that has been obtained and collected, the data will then be reduced, presented, and verified. Conclusions will be obtained by statistical analysis, looking for the relationship and influence between several variables.

\subsection{FLOW DIAGNOSTTHE RESEARCH PROCESS}

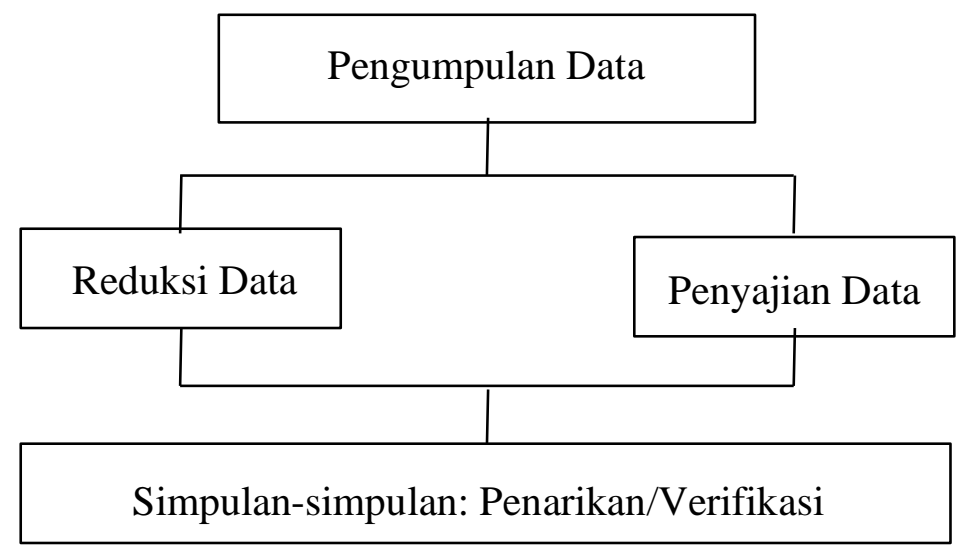




\section{CHAPTER III}

\section{OFRESEARCH RESULTS}

Our research data uses descriptive quantitative methods with the flow of data collection, analyzing the data that has been collected, and drawing conclusions. Data was collected using a structured interview technique, in which the interviewer provided questions related to the topic being researched along with multiple-choice answers. With the help of online media (google forms), we provide nine questions and answer choices that are in accordance with the big title of Language Ethics in Daily Life from the perspective of norms, gender, and region.

After determining the target respondents, we distributed the questionnaires for almost a week and received various responses from a total of 60 respondents. The characteristics and data of respondents in this study will answer questions through an online questionnaire whose focus will be divided into three parts, namely norms, gender, and region. This questionnaire will assist our research in analyzing the attitudes, beliefs, and characteristics of respondents regarding the topic being studied.

\section{Indonesia has a diversity of languages. Among these there are differences in use for} older people. In Javanese, for example, there are differences in the use of krama inggil and krama alus. Did you learn that language?

Based on the results of the questionnaires that we have distributed, 27 of the 60 respondents answered that they learned the polite language of their respective regions while the other 26 respondents only learned the language little by little because they heard friends or relatives speak the language, 7 respondents answered no. never learned the polite language of their area. we can conclude for this question that there are still many people who want to know and want to learn the polite language of their respective regions so that respondents can be accepted in the community.

\section{If you study a regional language, do you use it in your daily life?}


For answer number two, 33 out of 60 respondents answered that sometimes they use the polite language of their area, according to our analysis because few of them really learn and understand the polite language of their area.

3. Do you think that passing on local languages to the next generation is important?

The answer to this question is that all 60 respondents agreed that it is important to pass on local languages to the next generation. So that the regional language is preserved. Over time, in this era of globalization, there are many reasons why foreign languages are important to master. In fact, on several occasions, foreign languages have entered the education curriculum in Indonesia. So, it would be nice, to balance, the regional language is still spoken regularly in the environment of the speaker. Maybe between family and close friends.

\section{Is the way of speaking for women taught different from how men should speak around you?}

This question resulted in two camps. The first camp is 32 respondents answered no, and the other camp as many as 28 respondents answered yes.

5. Have you ever heard the saying that the way women should speak is a soft tone and shouldn't shout? Or should men speak sternly?

52 respondents answered that they have heard because it is often good at school or in the community that it is said that girls should speak softly and not raise their voices because they are considered impolite, while boys are obliged to speak firmly to be more respected.

\section{In your opinion, should the way of speaking used by women and men be different?}

43 respondents answered that they did not have to be distinguished and 17 of them answered that they had to be distinguished.

\section{How do you judge a person's ethics, morals, and morals?}


This question resulted in many responses from 60 respondents who answered. The answer that has the most respondents is a way of thinking or behave, as many as 31 respondents. Then, the second answer that has the most respondents is the daily behavior of a person as many as 21 respondents. The other answers were chosen by several respondents but not in large numbers, including their social circle in the family or friends, chosen by 3 respondents, a person's religious attitude was chosen by 2 respondents. In addition, the answers were filled in independently by the respondents through thefeature, others namely behavior and how to talk to other people, behavior and relationships, and agreed with all the options given, each having one respondent.

\section{Do you agree with the statement, "A person who has no morals is like an animal that does not have good moral values." ?}

Thirty-four respondents answered agree with the statement above because politeness is one of the differences between animals and us. Therefore we must have ethics or politeness values so that our lives become more orderly.

\section{If studying ethics is essential, which of the following options is your goal in studying ethics?}

The answer to this question yields six different answers. Eighteen respondents answered to deliver a better life, 15 respondents answered to become a rational and responsible thinking tool, 17 respondents answered to have a depth of attitude and responsibility in life, eight respondents answered the option of getting the same concept of good and bad judgment for all humans in space and time, one respondent answered sefforts not to harm others, one other respondent answered to be a civilized human being and can be an example. 


\section{CHAPTER IV}

\section{DISCUSSION}

In this section, the researcher will discuss the results of the research through a circular Google Form regarding Language Ethics in Daily Life which is addressed to the respondents. By sharing questions via Google Form, and will be analyzed by us researchers to find answers to the questions that have been distributed. The method used in this research is the descriptive qualitative method. According to Sugiyono (2016:9) method descriptive is a research method based on the philosophy of postpositivism used to examine the condition of a natural object where the researcher is the instrument.

In the first question, the researcher discusses whether there is still use of language with age differences, for example, found in Javanese, such as krama inggil and krama alus. It can be concluded that almost half of the respondents still use the language so that there is still interest from the community to learn the traditional language, especially in today's modern era.

The next question, the researcher discusses the use of traditional language that is practiced in everyday life. More than half of the respondents still use the language. Therefore, it can be concluded that there are still people who practice traditional languages in the family environment and outside the family in daily communication.

The third question, the researcher discusses the importance of passing down traditional languages to the next generation. One hundred percent of respondents agree that it is very necessary. The conclusion obtained is that there are still many people who care about preserving traditional languages and need to be passed on to their children and grandchildren or the next generation.

The fourth question, regarding the differences in speech between women and men. In this question, the respondents are divided into two. Fifty-three percent of respondents disagreed with this statement. 
The fifth question is, have you ever heard a saying that women should use a soft tone of speech and should not shout while men should speak firmly? 86\% of respondents agree with this, therefore the conclusion obtained is that there is still a belief that women's own judgment is seen from good speech.

The sixth question, is there really a difference between the ways of speaking used by women and men? $71 \%$ of respondents chose no, i.e. judged that the way men and women should speak should not be distinguished, while $28.3 \%$ agreed that the way of speaking should be differentiated according to gender. Generally, speaking etiquette begins in the home environment. Especially Javanese families, usually women will naturally be educated to speak softly and not raise their voices. $28.3 \%$ of respondents who agree that they may have been educated in their life to speak according to the customs of their respective tribes.

The seventh question, is how do respondents assess a person's ethics, morals, and morals?, $50 \%$ or half of the respondents answered that judging someone is based on their behavior and the way they talk to other people. From this, it can be concluded that society is still concerned with how the words of other people affect the views of ethics, morals and morals.

The eighth question, is the respondent's agreement with the statement that people who do not have morals are like animals who do not have good decency values. $56 \%$ of respondents agree with this idea, where they feel that moral decency is one of the important roles in a person, especially in treating others.

In the last question, the researcher gave the respondent an option about whether it was your goal to study ethics. Most choices are divided into two answers with $28 \%$ each. First, respondents agree that the purpose of studying an ethics is to lead to a better life. The next respondent answered that the purpose of this was to take responsibility for life. It can be concluded that many people agree that both answers are equally important in the purpose of studying ethics. 


\section{CHAPTER V}

\section{CONCLUSION}

From the explanation above, it can be concluded that, first, the essence of learning language ethics is a formal thing experienced by every society in daily life. The aspect of ethical learning needs to be a concern with regard to attitudes in social interactions both in daily life and in the social environment of society. Learning language ethics contains the essence of skills in using language according to the needs and or situations of its use following the social context at hand. Second, language politeness and ethics have a significant role in character development efforts for the Indonesian people. Politeness has become a crucial thing for the Indonesian Nation. If the future successors of the country are taught the values of politeness, it starts with being taught how to have ethics when talking to all groups, which is very important later in real life. And the third, as discussed above, how important it is for us to preserve or reduce the polite or formal language of our area, is to keep that culture alive and known by the citizens or the community itself, which of course has become part of the identity of the area. Therefore, we can state how important it is to teach language ethics, especially formal language or manners from their respective regions,

which is very important to teach so that our successors have morals and a culture and identity where others have not. Certainly have that. Language ethics itself is needed in any aspect, for example, in terms of work. Studying good and correct ethics or speech will be very influential, starting from a comfortable work atmosphere to being able to show respect and mutual respect. 


\section{REFERENCES}

Intan, T., \& Mariamurti A. (2019). Uncovering Beauty Myths and Consumer Culture in the Chick Lit Beauty Case by Icha Rahmant. Malang: State University of Malang.

Miftakhuddin. (2020). Approaches to educational research: An Overview from the Perspective of the Philosophy of Science. Yogyakarta: Yogyakarta State University.

Ridlwan, R., \& Rahardi, K. (2021). Constructing a Local Literature Force with Literary History Research: A Conceptual View. Blitar: UNU Blitar.

Inscription D., \& Sugiarti. (2020). A Study of Neurotic Anxiety in Nunuk Y. Kusmiana's Novel Shrill Cassowary Bird. Surabaya: Muhammadiyah University.

Sidiq M., \& Manaf, A. (2020). Characteristics of Directive Speech Acts The protagonist in the Novel Cantik Itu Luka by Eka Kurniawan. Surabaya: Muhammadiyah State University.

Ari, D., \& Suadyana, E. (2021). Yoga Literature: The Author's Way of Unity in Marriage Literature. Denpasar: Indonesian Hindu University.

Miftakhuddin. (2021). Children's literature: Genre realisme. Yogyakarta: Yogyakarta State University.

Hartati, D., Jamal, H., \& Sita., Nur. (2021). A Comparative Study of Literature from Misguided Novels with Layla Majnun's Novels: A Psychological Approach to literature. Surabaya: Muhammadiyah University.

Artika. (2021). Literature and Plague. Denpasar: Ganesha University of Education.

Artika. (2021). Literature and Reality: Textbook of the Sociology of Literature. Denpasar: Ganesha University of Education.

Saragih, K., Maniak, N., \& Samosir, Y. (2021). Imagination Relationship With Novel Literature. Medan: Medan State University. 
want. (2020). Digital Curation of Cyber Literature: A Conventional Literary Perspective. Jakarta: University of Indonesia.

Zustiyantoro. (2021). Literacy and Literature: An Encounter. Semarang: Semarang State University.

Munaf, S., Muradi, S., Mubarak, F., \& Noor, F. (2021). Lughawiyyat Journal of Arabic Language and Literature Education. Pasuruan: IAI Dalwa.

Firmansyah. (2021). Multimodal Literature Learning. Pasuruan: PGRI Wiranegara University.

Endaswara. (2021). Alternative Literary Learning Posthumanism. Yogyakarta: Buana Pustaka

Kurniawan. (2020). Librarianpreneur in the Digital Age. Yogyakarta: University of Muhammadiyah Yogyakarta.

Saputra. (2021). Collaborative Learning in theAge Digital. Yogyakarta: Creative Diandra / Mirra Buana Media

Huda. (2019). Sketch of Archipelago Islamic Studies in the Philosophy of Science Perspective. Surabaya: UIN Surabaya.

Suhardi. (2021). BAHTERA: Journal of Language andEducation Literature. Riau: Raja Ali Haji Tanjungpinang Maritime University.

Soepardjo, D., Suyatno., Sulaiman., \& M.Kharis. (2020). 13 Language and Literature Learning Innovations. Malang: State University of Malang.

Ariyana, Semiba. (2019). Evaluation of Indonesian Language and Literature Learning. Bengkulu: Bengkulu University.

Sumarno. (2020). Content Analysis in Language and Literature Learning Research. Lampung: Muhammadiyah University of Kotabumi

Furqani. (2019). Are Reading Skills Needed in Learning Indonesian Language and Literature?. Palembang: PGRI Palembang University. 
Setyowati, L., \& Sukmawan. S. (2020). Adapting to Change: Language and Literature Learning in the Pandemic Era. Makassar: Delta Pijar Publishing.

Grace. (2020). The Role of Mass Media in the Context of Fostering Indonesian Language and Literature. Makassar: Makassar State University.

Nugroho. (2021). View of Philosophy as a Nursing Philosophy Based on Social Science Clusters. Probolinggo: Nurul Jadid University.

Ningrum. (2020). Benefits of Philosophy of Science. Semarang: Diponegoro University.

Rohmah. (2019). Scope of Philosophy of Science. Madura: IAIN Madura.

Daughter. (2019). The Relationship Between Philosophy With Science. Malang: Brawijaya University.

Handoyo, E., \& Ekaningsih, L. (2021). Science philosophy. Semarang: State University of Malang.

Rahmawati, E., \& Achsani, F. (2019). The Moral Values of Peter's Novel by Risa Saraswati and Its Relevance to Indonesian Language Learning. Surabaya: Muhammadiyah University of Surabaya.

Erawati, Y. (2020). Female Characters in M. Rasyid Manggis' Kaba Sabai Nan Aluih and Vera Yuana's Senandung Sabai Novel (Comparative Literature Study). Surabaya: Muhammadiyah University of Surabaya.

Aswan. (2019). Portraits of Husband and Wife Sexuality in the Best Indonesian Short Stories Collection in 2008. Surabaya: Muhammadiyah University of Surabaya.

Subiharto, F. (2019). Structural Analysis in the 2011 Fantasy Fiesta Fantasy Story Anthology as Literature Learning Material for Class VII MTs Insan Kamil Warungkiara for the 2018/2019 academic year. Surabaya: Muhammadiyah University of Surabaya.

Praningrum, HI. (2021). The image of a woman in a short story is a pair of eyes imprisoned, and the woman was once beautiful. Surabaya: Muhammadiyah University of Surabaya. 
Irma, C. (2021). The Image of the Main Female Character and the Value of Character Education in the Novel Carnation by Sanaz Nadya. Surabaya: Muhammadiyah University of Surabaya.

Hermawati, Y., \& Devi, S. (2019). The desire for freedom of the character 'You' in the novel Gentayangan by Intan Paramaditha. Surabaya: Muhammadiyah University of Surabaya.

Anggarista, R. (2020). Environmental Wisdom in the Novel Wandering in the Jungle by Mochtar Lubis. Surabaya: Muhammadiyah University of Surabaya.

Fazalani, R. (2020). Gendang Belek Art of the Sasak Tribe Society as Traditional Culture. Surabaya: Muhammadiyah University of Surabaya.

Gemilang, M. (2020). Male Beauty Advisor Masculinity in Surabaya. Surabaya: Airlangga University.

Sofyani, I. (2020). Sexist Practice in Surabaya Public Service Room. Surabaya: Airlangga University.

Galang. (2019). Human Freedom in Abe Kobo's Suna No Onna Novel: A Study of Sartre's Existentialism. Surabaya: Airlangga University.

Immortal, Noer. (2020). Pedophilia is a crime of morality from the perspective of child protection. Surabaya: Airlangga University.

Tantri, Veda. (2020). The State's Responsibility in Protecting Human Rights for Victims of Sexual Violence. Surabaya: Airlangga University.

Hidayah, Nur. (2020). Gender Discourse in Mata Najwa Episode "Politics of Women”. Surabaya: Airlangga University.

Geleuk, M. (2019). Gender Construction on Women's Identity in Ayu Utami's Larung Novel. Surabaya: Airlangga University.

Dany, R. (2020). The Form of Language Politeness for Airlangga University Students: A Study of Pragmatics. Surabaya: Airlangga University. 
Zulfa, A. (2020). Human, Nature, And Science: An Ecocritical Reading On Terry Prachett's Nation. Surabaya: Airlangga University.

Na'im, H. (2020). The Representation Of Muslims In Eye In The Sky (2015) Movie. Surabaya: Airlangga University.

Sugiyanto (2020). Changes in the Meaning of the Spirituality of the Seblang Ritual in Banyuwangi Regency in the Perspective of Gadamer's Hermeneutics. Surabaya: Airlangga University.

Renitasari, Dewi. (2020). The Influence of Ethical Ideology and Religiosity on Auditor's Ethical Considerations. Surabaya: Airlangga University.

Arvita, R. (2020). Disclosing the Behavior of Tax Consultants in Enforcing Professionalism Ethics. Surabaya: Airlangga University. 